\title{
Islamic Spain 1250-1500
}

\section{By L. P. Harvey. Chicago: The University of Chicago Press, 1991, $400 \mathrm{pp}$.}

This book presents a remarkable account of the political history of Andalusia (Muslim Spain) during the last phase of its existence. The author adopts a cyclical approach in the sense that he traces the creation of the Banū Nașr kingdom in Granada, its development, and its decline and fall. He studies the period of each ruler in chronological order from the establishment of the kingdom of Granada to its collapse. Instead of limiting himself to description or repetition, he chooses to adopt an analytical approach which permits him to deepen our insight regarding the period of each ruler. He reproduces a clear picture which combines internal political developments and external relations with the Christians.

The author studies the history of the Muslims of Granada as well as those in Christian Spain up to the Christian conquest of Granada. He is correct in including these two categories, for the religious, cultural, and linguistic criteria unite these two groups, and also because their fates became similar after the fall of Granada in 1492. Thus both groups can be considered "Moriscos," a topic which Harvey started working on over thirty years ago.

The book is not easy to read, because it reflects many years of research and has tremendous cultural weight. To the author's obvious strenuous intellectual effort, one may add his intellectual integrity as a distinguished scholar who is credible in the West and in the East alike, something which not all orientalists can claim. He is critical of the history which he studies and its sources without being offensive; the distorting influence of a personal dimension found in other historians is here minimized. The author criticizes himself before being critical of others. His manner of presenting and interpreting history is convincing, as his intentions are exclusively scholarly. The author is a member of a breed that is not very common in the politically oriented European and North American universities with regards to anything related to Islam and Muslims. This is not to say that he is beyond criticism, however, as the book could be faulted for not having relied directly on some of the fundamental and primary Andalusian sources. We could disagree with his approach and suggest other approaches. Fortunately for his readers, the author is perhaps more conscious of his limitations than anybody else, which is also why he did what he proposed to do so admirably. 
This book is not merely a new contribution to the study of a period in Andalusian history for which there is very little in English, nor is it just one more contribution to commemorate Christopher Columbus' discovery of America. It is rather a new contribution, based upon the study of new material, to our understanding of this period. The author presents new interpretations of events and historical trends as well as a critical analysis of the primary and secondary sources. This work further stands out due to its methodology because, without neglecting the normal preoccupations of a professional historian, it is characterized by the professional application of literary criticism, a feat which few historians can match. Harvey can do this because he is first and foremost a professional philologist who dealt with problems of language even before the term "linguist" became so prevalent.

If there is one predominant feature in this book, it is the author's tendency to seek the maximum precision in every feature or theme under examination. In the first chapter, entitled "Geographical, Environmental and Historical Contexts," he defines the human component of his subject matter by dividing it into numerous subcategories, examines problems of demography, and then attempts to determine the correct population of Granada and other areas of Andalusia. He concludes by presenting a new map of the Iberian Peninsula which resulted from the moving frontier as the Christian advance against the Muslims of Granada progressed.

The book is entitled Islamic Spain 1250-1500, but what the author actually studies is the Muslims of Spain during this period. The human factor is in fact omnipresent. This study is not one of institutions, although institutions are discussed, and neither is it essentially one of historical phenomena, although the latter are included. It is rather a study of a human group with its different components. Different chapters study these subgroups, and together they form a unified body. The author's precision is again clear here. For example, while most of the chapters deal with the Muslims in Granada, the author examines the Muslim minorities in Castile (chapter 6), Aragon (chapter 7), Valencia (chapter 8), and Navarre (chapter 9), stressing both their similarities and differences. He gives the Muslim inhabitants of Granada an altogether different treatment, which is of course understandable, for the people were different, their conditions were different, and so are the sources for studying them. Al Wansharāsīs Mi'yār al Ikhtiyār is not the same as the Siete Partidas.

However, the part on the Muslims of Granada from chapter 10 to the end of the book is, in my view, more important than the previous chapters, because the author's personal contribution is more clearly reflected here. In the chapters on the Muslims in Christian Spain (al mudajjanūn or Mudejars) the author relied heavily on eminent specialists like Robert Burns for Valencia, Mercedes García Arenal for Navarre, and Ladero Quesada for Castile. This is an acceptable choice, due to the high scholarly level of these studies. However, the subject 
of the Mudejars is itself difficult because, as the author claims:

The subject Muslims of the Christian kingdoms sought to have no history, to live discreetly and unperceived . . .publicity was more likely to bring them harm than advantage. Within the Islamic community as we have seen, the advice that they would receive would be to end their plight by emigration to an Islamic state. Within Christendom, to attract the attention of the enthusiastically pious would bring disastrous consequences (p. 68).

The author's study of the Muslims in Granada in chapter 2 and, later on, in chapters 10 to 18 , was therefore more detailed. The dates are specified and the historical context of Granada's development is examined meticulously through textual analysis and interpretation.

Harvey's examination of the Nașrid kingdom in Granada is interesting, because the narration stands out as a detailed internal presentation of this history and due to the precision of dates and events which has resulted from his close textual analysis of a rich variety of many Andalusian, Maghribi, and Christian sources. The fruit of this undertaking is a blend of historiography which presents the history of the Banū Nașr in Granada as few historians have been able to do. The analytical approach reflects the author's linguistic formation, and the result is a precise internal presentation of the creation, development, and collapse of Granada and its social environment.

It would take too long to examine the different themes studied by Harvey, including relations between Granada and the different Christian kingdoms, as well as the Banū Mārin rulers in the Maghrib. The author examines changing coalitions, treaties between Muslims and Christians, battles at sea and on land, politics and religion, and so on. He relies on Andalusian primary and secondary sources. The history of the Nașrid kingdom of Granada is characterized by contradictions of all sorts, the involvement of an infinite number of elements and influencing factors, and an ever changing historical trend. He asks questions, proposes solutions, and tries to decipher the history of Granada from the midthirteenth century to the end of the fifteenth century.

Finally, I would like to conclude with a comment that I made previously, namely that the author did what he proposed to do admirably. By linking the Mudejars with the Andalusian Muslims of Granada, he presents the question of Andalusian history during the latter part of its development in a new light. He has of course been able to present this synthesis thanks to the recently produced and high quality work on the Mudejars and also on certain aspects of Granada's history under the Banū Nașr, although this subject continues to be wide open for serious research.

Harvey's work is significant not only because it is an important contribu- 
tion to a field in need of further study, but also because of its methodological innovation. For example, even though the subject is fundamentally the same as the one studied by Rachel Arie in her synthesis of the history of Granada, Lhistoire musulmane au temps des Nasrids (1232-1492), the result is radically different, for the method and approach are different. The formation of the authors is also different, as are the objectives which they sought to achieve. Harvey's empiricist tendency contrasts with Arie's rationalist trend. The periods during which both books were written also differ. Arie's synthesis of Granada's history is comparable to what Levi-Provencal did for the history of Andalusia up to the end of the tenth century in his Histoire de l'Espagne musulmane, although the latter was more profound and successful. Harvey benefitted from some excellent scholarship on his subject, including a number of specialized studies on specific areas such as Navarre or Aragon. The fundamental difference between the two works is perhaps that Arie presented a general outline for researchers to follow, while Harvey relied on specialized studies and his own research to present a profound synthesis specialization, thus contributing to Andalusian historiography as a linguist. This book is actually a demonstration of how linguistics could contribute to historiography and vice versa.

The author is sincere and credible in what he does without claiming to be so, because he does not need to do so. Here is a Westerner who does not write about the East as an abstract notion, but rather as a historical human experience. His intellectual integrity is manifested throughout the book in numerous ways. For example, one footnote reads: "I am indebted to Dr. Hossein Bouzineb of the University of Rabat for allowing me to see a draft of an article entitled 'Respuestas de jurisconsultas magrebies en tornoa la inmigración de musulmánes hispánicos' ..." (pp. 57-8). This acknowledgment by the author is for someone who is a generation younger than he is. The dedication is for "Shaykh Zaki Yamani with gratitude and respect." Anyone who knows Dr. Bouzineb will realize that this acknowledgment is well deserved, as is the dedication to Shaykh Zaki Yamani. The point to make here is that the author deals with non-Western scholars as scholars, not as objects. This may appear to be obvious, but its application in the West is far from common. Fortunately, there are exceptions to the rule, and Harvey is one of them.

\author{
M'hammad Benaboud \\ Faculty of Letters \\ University of Tetuan \\ Tetuan, Morocco
}

